\title{
PEMBIAYAAN MUDHARABAH, RISIKO DAN PENANGANANNYA (Studi Kasus pada Bank BTN Kantor Cabang Syariah Malang)
}

\author{
Friyanto \\ STIE Indonesia Malang \\ Email: fri.friyanto@gmail.com
}

\begin{abstract}
Abstrak
Pembiayaan Mudharabah adalah bentuk kerja sama antara dua pihak atau lebih, yang mana pemilik modal mempercayakan sejumlah modal kepada pengelola dengan perjanjian pembagian keuntungan. Risiko dari pembiayaan mudharabah adalah asimetri informasi serta moral hazard. Tujuan penelitian ini adalah memahami dan meminimalisasi risiko serta memahami alternatif solusi. Penelitian ini merupakan penelitian studi kasus dengan metode problem solving. Obyek penelitian adalah Bank BTN Kantor Cabang Syariah Malang. Hasil penelitian menunjukkan bahwa risiko dapat diminimalisasi dengan menentukan syarat-syarat yang harus dipatuhi oleh nasabah.
\end{abstract}

Kata kunci: Pembiayaan Mudharabah, Risiko.

\begin{abstract}
Mudharabah is a cooperation between two or more parties, in which the owner of the capital entrusts the manager, amount of capital with profit-sharing agreement. The faced risks are information asymmetry and moral hazard. The purposes of this study were to minimize the risks and understand the solutions. This research used problem solving method. The research object was BTN Syariah Malang Branch. The result of this study indicated that the risks can be minimized by determining specific conditions that must be obeyed.
\end{abstract}

Keywords: Mudharabah financing, Risks.

\section{PENDAHULUAN}

Bank syariah memberikan pembiayaan dengan prinsip mudharabah dan musyarakah, bertransaksi jual beli dengan prinsip murabahah, salam, dan istisna', serta menyewakan aktiva dengan prinsip ijarah di samping produk lainnya, seperti rahn dan qardhul-hasan. Risiko dapat didefinisikan sebagai suatu potensi terjadinya suatu peristiwa (events) yang dapat menimbulkan kerugian. Risiko yaitu suatu kemungkinan akan terjadinya hasil yang tidak diinginkan, yang dapat menimbulkan kerugian apabila tidak diantisipasi serta tidak dikelola semestinya. Risiko dalam bidang perbankan merupakan suatu kejadian potensial baik yang dapat diperkirakan (anticipated) maupun tidak dapat diperkirakan (unanticipated) yang berdampak negatif pada pendapatan maupun permodalan bank. Risiko-risiko tersebut tidak dapat dihindari namun dapat dikelola dan dikendalikan.

Karim (2001) menegaskan bahwa munculnya asimetri informasi pada kontrak mudharabah karena mudharib sebagai agen memiliki lebih banyak informasi pada dua aspek yaitu; (1) mudharib mendesain kontrak dengan shahib al-maal, sehingga mudharib lebih memiliki kemampuan untuk mengobservasi permintaan maupun produktivitas usaha (2) hanya mudharib yang mampu mengobservasi tingkat usaha dan upaya yang telah dilakukan tanpa campur tangan shahib al maal.

Guna mengurangi risiko yang disebabkan oleh asymetric information dan moral hazard tersebt, maka pihak bank syariah menetapkan beberapa syarat yaitu (Karim, 2001): (1) peraturan mengenai syarat porsi modal dari pihak peminjam lebih besar, (2) peraturan mengenai syarat agar peminjam melakukan kegiatan bisnis yang memiliki risiko lebih kecil (3) peraturan yang mensyaratkan agar peminjam melakukan bisnis dengan arus kas yang transparan, (4) peraturan yang mensyaratkan peminjam melakukan kegiatan bisnis yang memiliki biaya terkontrolnya rendah, (5) menetapkan nilai maksimal rasio hutang terhadap modal, (6) menetapkan jaminan aset tetap dan (7) mensyaratkan adanya jaminan dari perorangan yang apabila terjadi kerugian bersedia mengambil alih kewajiban peminjam. Selain tujuh 
syarat tersebut, upaya untuk mengendalikan risiko ditempuh dengan melakukan inspeksi mendadak, monitoring secara periodik, melakukan audit atas laporan keuangan, menetapkan revenue sharing dan menetapkan minimal profit margin.

Secara spesifik risiko-risiko yang akan menyebabkan bervariasinya tingkat keuntungan bank meliputi risiko likuiditas, risiko kredit, risiko tingkat bunga dan risiko modal (Muhammad, 2002). Secara umum jenis-jenis risiko yang dihadapi perbankan syariah adalah sebagai berikut (Harisman, 2002): (1) risiko likuiditas (liquidity risk), (2) risiko pasar (market risk), (3) risiko operasional (operating risk), (4) risiko penyelewengan (fraud risk), dan (5) risiko pembiayaan (financing risk). Seperti halnya bank konvensional, bank syariah juga menghadapi risiko pembiayaan dalam menyalurkan dananya ke masyarakat. Risiko pembiayaan atau sering disebut pula default risk merupakan suatu risiko akibat kegagalan atau ketidakmampuan nasabah (pengusaha) mengembalikan jumlah pinjaman/pembiayaan yang diterima sesuai jangka waktu yang ditentukan atau dijadwalkan.

Mudharabah atau penanaman modal adalah penyerahan modal uang kepada orang yang berniaga, sehingga ia mendapatkan prosentase keuntungan (Karim, 2001). Akad kerjasama ini melibatkan dua pihak di mana pihak pertama (shahibul maal) menyediakan seluruh pembiayaan, sedangkan pihak lainnya menjadi mudharib ataupengelola. Secara teknis al-mudharabah adalah akad kerjasama usaha antara dua pihak di mana pihak pertama (shahibul maal) menyediakan seluruh (100\%) modal, sedangkan pihak lainnya menjadi pengelola (Antonio, 2003). Menurut PSAK nomer 59 paragraf 6, mudharabah adalah akad kerjasama usaha antara shahibul maal (pemilik dana) dan mudharib (pengelola dana) dengan nisbah bagi-hasil menurut kesepakatan di muka.Keuntungan usaha secara mudharabah dibagi sesuai kesepakatan yang dituangkan dalam kontrak sedangkan apabila rugi ditanggung shahibulmaal (pemilik modal), selama hal itu bukan akibat kelalaian mudharib.
Berangkat dari fenomena tersebut, menurut penulis pemahaman risiko yang memiliki karakteristik berbeda harus dikelola dan bukan dihindari. Adanya risiko-risiko tersebut menimbulkan pada penulis untuk mengkaji lebih dalam mengenai implementasi dan penerapannya. Berdasarkan kondisi di atas penulis memandang bahwa memang masih banyak masalah yang ada pada pola pembiayaan mudharabah. Persoalan utama yang dikaji dalam tulisan ini adalah bagaimana meminimalisasi risiko pembiayaan mudharabah di Bank BTN Kantor Cabang Syariah Malang.

Dalam artikel ini, peneliti melakukan wawancara baik secara langsung maupun melalui kuesioner kepada petugas, pejabat bagian kredit/pembiayaan sebagai informan tentang implementasi pelaksanaan pembiayaan mudharabah serta melakukan evaluasi langsung pada berkas administrasi pembiayaan/kredit masing-masing debitur. Produk pembiayaan mudharabah yang menjadi bahan dalam penelitian ini adalah yang tergolong lancar maupun Non Performing Financing $(N P F)$ atau pada pembiayaan yang bermasalah. Pertanyaan-pertanyaan yang berhubungan dengan penelitian ini adalah: (1) pelaksanaan/ implementasi atas prosedur pemberian pembiayaan dalam bentuk kredit/pembiayaan mudharabah dan (2) pertanyaan untuk evaluasi secara langsung pada berkas akad pinjaman masing-masing debitur.

Saat ini skim pembiayaan murabahah masih mendominasi portofolio pembiayaan Bank BTN Kantor Cabang Syariah. Sampai akhir Desember 2008 saja total pembiayaan telah mencapai Rp 51.075 miliar dengan peningkatan $160 \%$ dari target rekap tahun 2008 atau portofolio sebesar 75 persen murabahah. Pembiayaan murabahah ditujukan untuk nasabah retail yang ingin memiliki KPR syariah, sedangkan target pembiayaan mudharabah dan musyarakah adalah para kontraktor atau developer perumahan.Implementasi pembiayaan mudharabah di Bank dilakukan pada triwulan pertama tahun 2006. Dalam Laporan Kinerja Keuangan Bank terdapat item-item pembiayaan yang melekat pada aset yang tercantum dalam Rencana KAP (RKAP) seperti pada Tabel 1.

Tabel 1. Aset Pembiayaan Bank BTN Kantor Cabang Syariah tahun 2006- 2007 (Dalam jutaan rupiah)

\begin{tabular}{lrrrrrr}
\hline \multicolumn{1}{c}{$\begin{array}{c}\text { REALISASI PEMBIAYAAN } \\
\text { (POKOK) }\end{array}$} & \multicolumn{1}{c}{ Renc } & \multicolumn{1}{c}{ Real. } & \multicolumn{1}{c}{ \%) } & \multicolumn{1}{c}{ Renc } & \multicolumn{1}{c}{ Real. } & $(\%)$ \\
\cline { 2 - 7 } MURABAHAH KPR SYARIAH & 12,312 & 24,127 & 196 & 26,040 & 36,561 & 140 \\
MURABAHAH KPR KONVERSI & 1,080 & - & - & - & - & - \\
MURABAHAH MULTIGUNA & 6,480 & 468 & 7 & 12,600 & 1,094 & 9 \\
MUDHARABAH & 1,440 & 100 & 7 & 2,250 & 3,490 & 155 \\
MUSYARAKAH & 1,440 & 2,760 & 192 & 2,250 & 4,250 & 189 \\
ISTISHNA & 1,080 & - & - & 2,100 & - & - \\
LAINNYA & 648 & - & - & 1,260 & - & - \\
JUMLAH & 24,480 & 27,456 & & 46,500 & 45,395 & \\
\hline
\end{tabular}

Sumber: Laporan Kinerja Bank BTN Kantor Cabang Syariah Malang tahun 2006-2007. 
Tabel 2. Aset Pembiayaan Bank BTN KantorCabang Syariah tahun 2008- 2009

(Dalam jutaan rupiah)

\begin{tabular}{lrrrrrr}
\hline \multicolumn{1}{c}{$\begin{array}{c}\text { REALISASI PEMBIAYAAN } \\
\text { (POKOK) }\end{array}$} & \multicolumn{1}{c}{2008} & \multicolumn{3}{c}{2009} \\
\cline { 2 - 7 } Menc. & \multicolumn{1}{c}{ Real. } & \multicolumn{1}{c}{$(\%)$} & \multicolumn{1}{c}{ Renc. } & \multicolumn{1}{c}{ Real. } & \multicolumn{1}{c}{$(\%)$} \\
\hline MURABAHAH KPR SYARIAH & 32,000 & 51,075 & 160 & 43,050 & 58,806 & 127 \\
MURABAHAH KPR KONVERSI & - & - & - & - & - & - \\
MURABAHAH MULTIGUNA & 7,500 & 186 & 2 & 1,950 & 663 & 34 \\
MUDHARABAH & 4,500 & 6,260 & 139 & 20,500 & 39,297 & 191 \\
MUSYARAKAH & 3,000 & 4,025 & 134 & 6,500 & 7.280 & 112 \\
ISTISHNA & 2,500 & 5,533 & 221 & 4,250 & 4,973 & 117 \\
LAINNYA & 500 & 985 & 197 & 2,760 & 1,584 & 57 \\
JUMLAH & 50,000 & 68,063 & & 79,010 & 108,603 \\
\hline
\end{tabular}

Sumber: Laporan Kinerja Bank BTN Kantor Cabang Syariah Malang tahun 2008- 2009.

Dari data tersebut pada Tabel 1, terlihat bahwa tahun 2006 realisasi aktiva pembiayaan (pokok) murabahah KPR 87,88\%, murabahah multiguna $1,71 \%$, mudharabah $0,36 \%$, musyarakah $10 \%$, istishna dan lainnya masing-masing sebesar $0 \%$. Selanjutnya pada tahun 2007 realisasi aktiva pembiayaan murabahah KPR 80,54\%, murabahah Konve 0\%, murabahah multiguna 2,41\%, mudharabah 7,69\%, musyarakah 9,36\%, istishna dan lainnya masing-masing tetap sebesar $0 \%$.

Pada Tabel 2, realisasi aktiva pembiayaan (pokok) tahun 2008 murabahah KPR 75,04\%, murabahah multiguna 0,27\%, mudharabah 9,20\%, musyarakah 5,91\%, istishna dan lainnya masingmasing sebesar 8,13\% dan 1,45\%. Dan pada tahun 2009 realisasi aktiva pembiayaan murabahah KPR $50,46 \%$, murabahah Konve 0\%, murabahah multiguna $0,61 \%$, mudharabah $36,18 \%$, musyarakah $6,70 \%$, istishna dan lainnya masing-masing sebesar $4,58 \%$ dan $1,46 \%$. Aktiva pembiayaan murabahah mengalami peningkatan paling besar yaitu pada tahun 2008 sebesar Rp. 51,075 milyar atau 160\% dan tahun 2009 sebesar Rp. 54.806 atau 127\% dari yang direncanakan. Hal ini diakibatkan oleh adanya implementasi pembiayaan murabahah yang direncanakan sebesar Rp. 32 milyar dan Rp. 43 milyar.Sesuai dengan rumusan permasalahan pada artikel ini yaitu bagaimana meminimalisasi risiko pembiayaan mudharabah di Bank BTN Kantor Cabang Syariah Malang, sebagaimana hasil wawancara dengan informan Manajer Operasional Bank disebutkan bahwa pembiayaan murabahah tidak terlalu berisiko dibandingkan pembiayaan mudharabah. Dalam catatan atas Kinerja Keuangan tidak dijelaskan secara detail bahwa nilai aktiva pembiayaan mudharabah pada tahun 2008 dan 2009 termasuk aktiva yang berisiko.

Pada Tabel 3 berikut ini adalah tingkat pembiayaan bermasalah/non performing financing (NPF) terhadap pembiayaan (netto) yang ada pada Bank BTN Kantor Cabang Syariah Malang dalam kurun waktu tahun 2006 sampai dengan tahun 2009.
Tabel 3. Tingkat NPF Bank BTN Kantor Cabang Syariah MalangPeriode tahun 2006 -2009

\begin{tabular}{ccccc}
\hline NPF & \multicolumn{4}{c}{ Tahun } \\
\hline$(\%)$ & 2006 & 2007 & 2008 & 2009 \\
\hline Rencana & 0,00 & 1,00 & 0,96 & 1,18 \\
Realisasi & 0,00 & 1,20 & 0,34 & 0,30 \\
Selisih & 0,00 & 0,20 & $(0,62)$ & $(0,88)$ \\
\hline
\end{tabular}

Sumber: Laporan Kinerja BTN Kantor Cabang Syariah Malang tahun 2006- 2009.

Pada Tabel 3 diketahui bahwa, NPF keseluruhan pembiayaan pada Bank pada tahun 2006 adalah sebesar 0\% mengalami kenaikan sebesar 1,20\% pada tahun 2007 yaitu menjadi 1,20\% atau ada kenaikan dari target $N P F$ tahun tersebut sebesar $0,20 \%$, namun pada tahun 2008 mengalami penurunan sebesar $0,86 \%$ yaitu menjadi sebesar $0,34 \%$ atau ada penurunan dari target $N P F$ tahun tersebut sebesar $0,62 \%$. Selanjutnya pada tahun 2009 sampai dengan bulan Agustus 2009 NPF secara keseluruhan dari pembiayaan mengalami penurunan yang cukup signifikan sebesar $0,04 \%$ atau menjadi $0,30 \%$ atau ada penurunan dari target $N P F$ tahun tersebut sebesar $0,88 \%$. Adanya penurunan $N P F$ ini akan menyebabkan efesiensinya biaya operasional bank yang kemudian berpotensi meningkatkan pendapatan nisbah bank. Berdasarkan informasi dari laporan tahunan RKAP pada Bank, diketahui bahwa sepanjang tahun 2009 tingkat NPF Bank perlu ditekan, sehingga Bank harus memfokuskan perhatian pada upaya-upaya pemeliharaan dan monitoring debitur secara konsisten terus menerus. Beberapa bukti berikut menunjukkan permasalahan yang telah peneliti dokumentasikan. Peneliti menelaah terdapat beberapa bukti masalah utama yang ditemukan dalam implementasi produk pembiayaan mudharabah, antara lain:

1. Keseriusan nasabah mudharib dalam menjalankan bisnis yang dibiayai bank. Dalam kenyataannya perusahaan-perusahaan mudharib/musyarik tidak selalu memenuhi harapan bank. Seringkali 
kewajiban-kewajiban atas pembiayaan kepada bank tidak dipenuhi dengan baik, perkembangan perusahaan tersendat-sendat bahkan ada kemungkinan menjadi pembiayaan macet.

2. Pelanggaran ketentuan yang telah disepakati sesuai perjanjian, sehingga dalam menjalankan bisnis yang dibiayai bank tidak sesuai lagi dengan kesepakatan. Adanya kekhawatiran dari bank terhadap penyalahgunaan penggunaan dana (side streaming) dimana nasabah tidak menggunakan dananya sesuai dengan apa yang tertera dalam perjanjian atau akad, bagaimanapun juga bank tidak mungkin mengawasi secara terus menerus.

3. Pengelolaan internal perusahaan mudharib/ musyarik yang belum dilakukan secara profesional sesuai standar pengelolaan yang disepakati antara bank dan nasabah.

4. Kelalaian nasabah mudharib dalam menjalankan bisnis yang dibiayai bank. Kenyataan ini menimbulkan banyak masalah. Nasabah (mudharib) masih menyembunyikan keuntungan usaha yang sesungguhnya, dan ini merupakan pemicu problema keengganan bagi bank syariah.

5. Bank syariah selaku pemilik modal (shahibul maal) masih belum yakin dengan kejujuran nasabah dalam melaporkan hasil usahanya. Dalam beberapa kasus masih terdapat nasabah (mudharib) yang tidak amanah (moral hazard).

Menurut Antonio (2003) risiko pembiayaan mudharabah antara lain adalah: (1) asymmetric information problem yaitu kecenderungan salah satu pihak yang menguasai informasi lebih banyak untuk bersikap tidak jujur. Oleh karena itu penetapan pembiayaan bagi hasil haruslah dilakukan dengan memperhatikan incentive compatible constraints (batasan-batasan untuk memberikan insentif bagi nasabah untuk berlaku jujur), (2) side streaming yaitu nasabah menggunakan dana itu bukan seperti yang disebut dalam kontrak dan (3) lalai dan kesalahan yang disengaja.

Dari uraian tersebut di atas, beberapa langkah yang diusulkan peneliti untuk menentukan alternatif pemecahan masalah tersebut antara lain: (1) Alternatif Pertama: menetapkan konvenan nilai maksimal rasio hutang terhadap modal, (2) Alternatif Kedua: menetapkan konvenan rasio maksimal aset tetap terhadap total aset, (3) Alternatif Ketiga: menetapkan konvenan diadakannya monitoring, (4) Alternatif Keempat: menetapkan konvenan bagi hasil dengan revenue sharing dan (5) Alternatif Kelima: menetapkan konvenan preferensi nasbah (mudharib) dengan menetapkan penghitungan dan pembayaran zakat. Berikut ini adalah beberapa alternatif tujuan pemecahan masalah yang diusulkan oleh penulis:
Alternatif Pertama: Menetapkan konvenan nilai maksimal ratio hutang terhadap modal.

Cara ini diajukan sebagai alternatif penulis dengan pertimbangan bahwa untuk mengurangi dan mengantisipasi risiko, maka bank syariah dapat menetapkan convenant (klausul) tertentu pada saat melakukan akad pembiayaan bagi hasil baik mudharabah maupun musyarakah.

Pada alternatif ini, bila porsi modal mudharib dalam suatu usaha relatif tinggi maka insentifnya untuk berlaku tidak jujur akan berkurang dengan signifikan, karena mudharib juga akan menanggung kerugian atas tindakannya itu. Dengan adanya konvenan tersebut akan dapat memperkecil masalah asimetri informasi atau agensi (agency problem) dalam pembiayaan bagi hasil. Asimetri informasi merupakan sesuatu yang pasti terjadi dalam kontrak mudharabah. Mudharabah atau penanaman modal di sini artinya adalah menyerahkan modal uang kepada orang yang berniaga, sehingga ia mendapatkan prosentase keuntungan (Karim, 2001).

Penelitian pada perusahaan kecil yang memperoleh fasilitas modal kerja tidak dijumpai adanya moral hazard jika dihubungkan dengan struktur kepemilikan dengan sales to asset ratio.Dengan demikian semakin tinggi tingkat kepemilikan maka efisiensi investasi semakin meningkat.Agency cost yang berhubungan dengan tingkat efisiensi investasi hanya terdapat kepada perusahaan nasabah yang mempekerjakan manajer dari luar (outsider manager). Agency cost pada perusahaan mudharib baru muncul dimana manajer berasal dari luar yang tidak memiliki modal perusahaan.

Alternatif Kedua: Menetapkan rasio maksimal aset tetap terhadap total aset

Salah satu persyaratan pengajuan pinjaman pembiayaan adalah adanya aset tertap berwujud yang dapat dijaminkan.Semakin besar nilai aset tetap berwujud yang dimiliki oleh nasabah ada kecenderungan semakin besar pinjaman yang dapat diperoleh. Oleh karena itu nilai aset tetap berwujud yang besar akan berpengaruh positif terhadap sumber penggunaan dana hutang/pembiayaan.

Alternatif pemecahan masalah kedua yang diusulkan penelitiyaitu dengan mengusulkan diadakannya konvenan (syarat) rasio maksimal aset tetap terhadap total aset pada bisnis mudharib/ musyarik. Secara khusus dalam konvenan ini adalah agar dana mudharabah tidak digunakan untuk investasi pada aset tetap secara berlebihan. Rasio maksimal bisa ditentukan misalnya sebesar $20 \%$.

Alternatif Ketiga: Menetapkan konvenan diadakannya monitoring. 
Penulis mencoba mengetengahkan alternatif berikutnya dengan menetapkan konvenan tentang monitoring baik monitoring terhadap usaha maupun monitoring transparansi keuangan (arus kas). Dalam konteks pembiayaan mudharabah, ada beberapa jenis dari bisnis mudharib yang tidak dapat dilihat secara transparan. Bila banyak dari arus kas mudharib yang tidak dapat diketahui secara transparan oleh shahibul maal, maka besarlah dorongan dan keinginan mudharib untuk berperilaku menyimpang. Contoh; pada pembiayaan mudharabah pada bisnis retail yang seluruh transaksinya menggunakan cash register akan memerlukan konvenan yang berbeda dengan pembiayaan mudharabah pada bisnis toko yang transaksinya tidak mengunkan cash register. Monitoring semacam ini dimaksudkan untuk mengambil sampel ada tidaknya penyimpangan arus kas.

Cara lainnya ditempuh dengan jalan meminta laporan keuangan audited atas laporan keuangan nasabah pada penyedia jasa keahlian-konsultan keuangan yang berkualifikasi dan berkompeten dalam hal ini melibatkan pihak ketiga sebagai auditor. Hasil penelitian Ahmed dalam Muhammad (2005) menawarkan salah satu cara untuk mengendalikan masalah agensi pada kontrak mudharabah salah satunya adalah aturan-aturan auditing. Dengan cara ini laporan keuangan nasabah akan diperiksa kebenarannya oleh pihak ketiga (auditor), sehingga pemilik dana (shahibul maal) benar-benar yakin bahwa laporan yang disampaikan tersebut benar adanya. Tujuan analisis aspek keuangan adalah untuk mengetahui kondisi usaha nasabah secara finansial, menentukan jumlah pembiayaan yang pantas dan wajar serta untuk mengetahui repayment capacity atau kemampuan nasabah untuk membayar pengembaliannya. Bank akan menganalisis keuangan perusahaan nasabah berdasarkan laporan keuangan yang disampaikan. Akan lebih kredibel apabila nasabah dapat menyampaikan laporan keuangan yang telah diaudit (audited) oleh Kantor Akuntan Publik.

Menurut Firdaus \& Aryanti (2003), petugas bank memiliki tugas monitoring dan pengawasan kredit/ pembiayaan, hal ini diperlukan sebagai upaya peringatan dini (earling warning) yang mampu mengantisipasi tanda-tanda penyimpangan dari syaratsyarat yang telah disepakati antara debitur/mudharib dengan bank yang mengakibatkan menurunnya kualitas kredit/pembiayaan untuk menentukan tingkat kualitas/kolektibilitas kredit yang bersangkutan dan dalam kebijakan perkreditan bank, setiap petugas bank harus mengatur dan mencantumkan tata cara penyelamatan dan penyelesaian kredit/pembiayaan bermasalah (non performing financing).
Adanya kontrol dan monitoring diperlukan sebagai upaya pengamanan yang diberikan oleh bank dengan terus memantau dan mengikuti jalannya perusahan nasabah, baik secara langsung maupun tidak langsung guna menghindari terjadinya penyimpangan-penyimpangan dengan cara mendorong dipatuhinya akad pembiayaan yang telah ditetapkan serta memberikan saran dan konsultasi agar perusahaan nasabah berjalan dengan baik.

Para staf profesional perbankan yang akan bekerja pada proyek pembiayaan musyarakah atas nama bank syariah, selama proyek berlangsung. Musyarakah biasanya diaplikasikan untuk pembiayaan proyek dimana nasabah dan bank bersamasama menyediakan dana untuk membiayaai proyek tersebut. Setelah proyek tersebut selesai, nasabah mengembalikan dana tersebut bersama bagi hasil yang telah disepakati untuk bank.

Alternatif Keempat: Menetapkan konvenan bagi hasil dengan akad revenue sharing

Cara ini diajukan sebagai alternatif penulis dengan pertimbangan bahwa untuk mengurangi dan mengantisipasi risiko, maka bank syariah dapat melakukan konvenan akad untuk pembagian hasil usaha dengan model revenue sharing. Dalam penerapan sistem bagi-hasil pembiayaan mudharabah ini salah satu teknik dalam perbankan yang harus diperhatikan. Menurut Sudarsono (2004) satu hal dalam teknik perbankan yaitu hasil pengelolaan modal pembiayaan mudharabah dapat diperhitungkan dengan dua cara yaitu: perhitungan dari pendapatan proyek (revenue sharing) dan perhitungan dari keuntungan proyek (profit sharing). Penetapan prinsip bagi hasil yang dipilih harus disepakati dalam akad.

Perhitungan pembagian hasil usaha dengan pendekatan revenue sharing akan lebih mudah, cara ini akan sangat membantu bankdi mana bank tidak memerlukan petugas yang memiliki spesifikasi khusus tentang bisnis tertentu untuk dapat memerlukan kontrol dan monitoringterhadap biaya-biaya yang dikelurkan oleh nasabah, tetapi tidak semua pembiayaan menggunakan akad revenue sharing. Menurut Karim (2001) salah satu panduan umum dalam incentive compatible constrains yaitu menetapkan konvenan (syarat) agar mudharib melakukan bisnis yang biaya tidak terkontrolnya rendah (lower fraction of noncontrollable cost). Dalam bisnis mudharib yang sarat dengan biaya tidak terduganya besar, tentu akan menjadi sumber perselisihan antara shahibul maal dengan mudharib tentang siapa yang harus menanggung biaya-biaya tersebut. 
Alternatif Kelima: Menetapkan konvenan preferensi nasabah (mudharib) dengan menetapkan pembayaran zakat

Cara ini diajukan sebagai alternatif penulis dengan pertimbangan bahwa implikasi dari segala bentuk kecurangan dan penipuan tidak dapat ditolerir dalam penentuan dan pembayaran zakat. Potensi masalah yang timbul dalam pelaksanaan kontrak mudharabah agar dapat mengatasi kelemahannya dapat dilakukan dengan beberapa cara salah satunya yaitu peningkatan kualitas preferensi mudharib dalam menerima amanah dari shahibul maal dan amanah dalam mengelola modal yang diberikan. Dalam hubungan tersebut Khalil, et al. (2000) dalam Muhammad (2005) menjelaskan bahwa prinsipprinsip agama dapat digunakan sebagai pengendali diri, meskipun seseorang dapat berbuat bohong (hazard), tetapi mereka dapat jujur dalam menyampaikan hasil usaha yang diperoleh.

Seperti dinyatakan oleh Triyuwono (1997) ketika individu melihat organisasi sebagai amanah maka konsekwensi paling penting adalah tujuan dan cara pencapaian tujuan itu sendiri yaitu etika. Kontrak mudharabah apabila dipandang sebagai amanah maka tujuan kemitraa tersebut tidak jauh dari makna amanah yaitu sebagai khalifahtullah fill ardh atau menyebarkan rahmat bagi seluruh alam. Triyuwono \& As'udi (2001) menyatakan bahwa eksistensi etika syariah dalam organisasi bisnis sebetulnya merupakan konsekwensi logis penggunaan metafora amanah. Aplikasi secara teknis metafora amanah dalam realitas kemitraan usaha adalah kemitraan yang dimetaforakan dengan zakat.

\section{PEMBAHASAN}

Selama tahun 2009 Bank BTN telah melakukan pengembangan budaya manajemen risiko di kantor cabang. Melalui Branch Risk Control Officer (BRCO), kantor cabang didorong untuk melaksanakan kegiatan sosialisasi standard operating procedure (SOP) secara berkala untuk meningkatkan dan menyegarkan kembali pemahaman pegawai atas prosedur operasional standar. Disamping untuk meminimalkan potensi risiko pada aktifitas operasional kantor cabang, kegiatan sosialisasi tersebut juga ditujukan untuk menjaga standar kualitas layanan kantor cabang.

Tabel 4. Matrik Pengambilan Keputusan

\begin{tabular}{|c|c|c|c|}
\hline \multirow{2}{*}{ No. } & \multirow{2}{*}{ Alternatif } & \multicolumn{2}{|c|}{ Pengambilan Keputusan } \\
\hline & & Keunggulan & Kelemahan \\
\hline 1 & $\begin{array}{l}\text { Menetapkan konvenan } \\
\text { maksimal rasio hutang } \\
\text { terhadap modal }\end{array}$ & $\begin{array}{l}\text { untuk berlaku tidak jujur akan berkurang } \\
\text { dengan signifikan, karena mudharib juga } \\
\text { akan menanggung kerugian atas } \\
\text { tindakannya }\end{array}$ & $\begin{array}{l}\text { melanggar ketentuan mudharabah, dan } \\
\text { sudah menjadi ketentuan musyarakah }\end{array}$ \\
\hline 2 & $\begin{array}{l}\text { Menetapkan konvenan } \\
\text { maksimal aset tetap terhadap } \\
\text { total aset }\end{array}$ & $\begin{array}{l}\text { perusahaan mudharib akan mengadakan } \\
\text { investasi dalam aset lancar, dengan } \\
\text { harapan perusahaan mudharib akan dapat } \\
\text { memperoleh kembali dana yang telah } \\
\text { diinvestasikan }\end{array}$ & $\begin{array}{l}\text { manajemen operasional usaha } \\
\text { sepenuhnya diserahkan pada mudharib, } \\
\text { bank tidak berhak dalam pengelolaan } \\
\text { usaha. }\end{array}$ \\
\hline 3 & $\begin{array}{l}\text { Menetapkan konvenan } \\
\text { diadakan monitoring }\end{array}$ & $\begin{array}{l}\text { memungkinkannya untuk menaksir } \\
\text { reputasi pengguna modal (mudharib), dan } \\
\text { dapat menginspeksi kegiatan operasi usaha } \\
\text { dengan lebih mudah dan terbuka }\end{array}$ & $\begin{array}{l}\text { (1) sumber daya manusia yang ada harus } \\
\text { dapat menguasai pemahaman terhadap } \\
\text { masing-masing bisnis nasabah } \\
\text { (mudharib), (2) high cost. }\end{array}$ \\
\hline 4 & $\begin{array}{l}\text { Menetapkan konvenan } \\
\text { bagi-hasil revenue sharing }\end{array}$ & $\begin{array}{l}\text { pendekatan yang mudah dan sangat } \\
\text { membantu bank, bank tidak memerlukan } \\
\text { petugas yang memiliki spesifikasi khusus } \\
\text { tentang bisnis tertentu untuk dapat } \\
\text { melakukan kontrol terhadap biaya-biaya } \\
\text { yang dikeluarkan oleh nasabah atau } \\
\text { mudarib }\end{array}$ & $\begin{array}{l}\text { bila nasabah tidak mampu menanggung } \\
\text { biaya (nafaqah) yang seharusnya } \\
\text { ditanggung nasabah, nasabah tidak akan } \\
\text { mampu untuk melanjutkan usahanya } \\
\text { sehingga akan merugikan bank sebagai } \\
\text { shahibul maal }\end{array}$ \\
\hline 5 & $\begin{array}{l}\text { Menetapkan konvenan } \\
\text { penghitungan dan } \\
\text { pembayaran zakat }\end{array}$ & $\begin{array}{l}\text { bank bertanggung jawab dan berhak untuk } \\
\text { turut ikut serta dalam mensosialisasikan } \\
\text { dan menempatkan harta dan atau uang } \\
\text { nasabah atau mudharib sebagai } \\
\text { obyek zakat }\end{array}$ & $\begin{array}{l}\text { realitas sosial sangat abstrak dan sulit } \\
\text { diukur serta rawan terhadap mereka yang } \\
\text { beritikad tidak baik sehingga diperlukan } \\
\text { usaha-usaha tambahan untuk mengawasi } \\
\text { mudharib melalui bentuk kerjasama } \\
\text { dengan semua institusi serta membangun } \\
\text { jaringan dengan para ulama atau tokoh } \\
\text { masyarakat setempat }\end{array}$ \\
\hline
\end{tabular}


Poin-poin penting dari hasil analisis dapat di ringkas dengan rangkuman matrik pengambilan keputusan dalam berbagai alternatif yang diusulkan seperti pada Tabel 4.

\section{RatioHutang Terhadap Modal}

Alternatif menetapkan maksimal ratio hutang terhadap modal tidak dipilih sebagai keputusan. Bila porsi modal mudharib dalam suatu usaha relatif tinggi, insentifnya untuk berlaku tidak jujur akan berkurang dengan signifikan karena mudharib juga akan menanggung kerugian atas tindakannya. Adanya konvenan tersebut dapat memperkecil masalah asimetri informasi atau agensi dalam pembiayaan ini.seperti model konvenan yang diajukan oleh Presley dan Session (1994) dalam Karim (2005) yang mencakup salah satu aspek yaitu menetapkan batasan agar porsi modal dari pihak mudharib-nya lebih besar dan atau mengenakan jaminan (higher stake in net worth and/or collateral). Alternatif ini melanggar ketentuan mudharabah, dimana secara teknis almudharabah adalah akad kerjasama usaha antara dua pihak di mana pihak pertama (shahibul maal) menyediakan seluruh modal, sedangkan pihak lainnya menjadi pengelola (Antonio, 2003).

\section{RatioAset Tetap Terhadap Total Aset}

Alternatif menetapkan rasio maksimal aset tetap terhadap total aset tidak dipilih penulis dengan pertimbangan bahwa untuk mengurangi dan mengantisipasi risiko, meskipun bank syariah dalam memberikan pembiayaan, dapat melakukan konvenan rasio maksimal aset tetap terhadap total aset akan sulit penerapannya.

Beberapa kendala/kelemahan dengan alternatif ini adalah sebagai berikut; pertama, money circulation yaitu sumber dana bank atau lembaga keuangan Islam yang sebagian berjangka pendek tidak dapat digunakan untuk pembiayaan bagi hasil yang biasanya berjangka panjang. kedua, adverse selection, yaitu (1) pengusaha (mudharib) dengan bisnis yang memiliki keuntungan tinggi cenderung enggan menggunakan kontrak mudharabah, (2) pengusaha (mudharib) dengan bisnis berisiko rendah enggan meminta pembiayaan mudharabah, sebaliknya bisnis yang berisiko tinggi sering menggunakan kontrak mudharabah, (3) pengusaha (mudharib) memberikan prospektus usaha atau proposal proyek yang terlalu optimis agar pihak bank tertarik. ketiga, adanya moral hazard yaitu pengusaha mempunyai dua pembukuan, yaitu (1) pelaporan yang diberikan kepada bank yang tingkat keuntungannya kecil, sehingga porsi ke- untungan yang diberikan kepada bank juga kecil, padahal pembukuan yang sebenarnya mempunyai keuntungan (2) yang berjumlah besar melalui creative accounting.

Beberapa faktor yang mempengaruhi character risk antara yaitu: (1) kelalaian nasabah dalam menjalankan bisnis yang di biayai bank, (2) pelanggaran ketentuan yang telah disepakati dan (3) pengelolaan internal perusahaan yang tidak dilakukan secara profesional sesuai standar pengelolaan yang disepakati antara bank dan nasabah. Analisis terhadap pembiayaan suatu perusahaan mudharib bila dilihat dari sales, cost, profits, assets dan liabilities serta cash flow adalah adanya risiko yang timbul dari perubahan kondisi bisnis nasabah mudharib setelah pencairan pembiayaan, biasanya adalah: (1) over trading dengan kata lain to much business with to little capital, sehingga akan timbul krisis cash flow, (2) adverse trading yakni mengembangkan bisnis dengan fixed cost yang besar serta bermain di pasar yang tidak stabil, sehingga akan menimbulkan high risk dan (3) liquidity run yaitu kesulitan likuiditas arus kas karena kehilangan sumber-sumber pendapatan dan peningkatan pengeluaran karena alasan yang tidak terduga (uncontrollable cost).

\section{Monitoring}

Mengingat pembiayaan yang dikeluarkan oleh bank mengandung risiko, maka dalam semua kegiatan yang terkait dengan pembiayaan harus didasarkan atas azas-azas dan kebijakan pembiayaan yang sehat, menguntungkan, konsisten, dan berkesinambungan.Menurut Karim dalam Muhammad (2005) monitoring secara acak dimaksudkan untuk mengambil sampel ada tidaknya penyimpangan. Cara ini diterapkan pada: (a.) bisnis yang skala usahanya tidak cukup besar untuk dilakukan monitoring secara periodik dan (b) bisnis musiman atau berjangka pendek.

Presley dan Session dalam Karim (2001) untuk mengendalikan atau meminimalisir kemungkinan terjadinya risiko asimetrik informasi (moral hazard), bank syari'ah perlu menerapkan batasan kepada mudharib antara lain menetapkan syarat agar mudharib melakukan bisnis dengan arus kas atau cash flow usaha yang transparan antara lain yang relevan dengan jenis usahanya dengan cara konfirmasi pada Bank Indonesia atas nama nasabah dan one obligor (satu kelompok peminjam dengan nasabah) yaitu untuk menjamin akurasi data IDI-Bank Indonesia.

Tujuan monitoring secara umum menurut Rickwood dan Murinde dalam Muhammad (2005) 
adalah sebagai berikut: (a) untuk menjamin efisiensi alokasi, (b) untuk menjamin pemenuhan batasan waktu, (c) untuk menjamin validitas informasi, (d) untuk memaksimalkan upaya agent, dan (e) untuk mendapatkan tanda-tanda informasi serta (f) Untuk menyingkapkan risiko. Pelaksanaan tindakan monitoring dapat dilakukan pada bidang-bidang sebagai berikut; (a.) pemantauan produksi, (b) kinerja keuangan, (c) batasan keuntungan (profitabilitas), (d) kemampuan atau kecakapan agent, (e) investasi dan (f) keuntungan personal agent.

Penulis cenderung memilih alternatif keputusan ini yaitu diselenggarakannya pengawasan (monitoring) usaha pada nasabah (mudharib). Pemahaman staf terhadap karakteristik bisnis usaha mudharib, item dan komponen biaya serta monitoring usaha tampaknya lebih penting dan akan berdampak pada berkurangnya risiko asimetri informasi dibanding dengan alternatif pertama dengan menetapkan nilai maksimal hutang/pembiayaan terhadap modal, alternatif kedua dengan konvenan pembatasan aset tetap dan keempat dengan konvenan pembagian bagi-hasil dengan revenue sharing serta kelima konvenan preferensi nasabah (mudharib) dengan penghitungan dan pembayaran zakat.

Namun demikian, dengan cara menambah konvenan monitoring tersebut terdapat beberapa kelemahan yaitu: (1) sumber daya manusia Bank BTN Kantor Cabang Syariah harus dapat menguasai pemahaman masing-masing bisnis nasabah (mudharib), sehingga waktu untuk kegiatan operasional sehari-hari bank menjadi tidak efisien, (2) high cost, bank harus mengeluarkan alokasi biaya dengan cermat pada perencanaan monitoring terhadap akadmudharabah maupun musyarakah, walaupun hal ini bisa di masukkan atau dibebankan sebagai biaya proyek musyarakah sesuai perjanjian/akad musyarakah.

Firdaus \& Aryanti (2003) menyatakan, petugas bank memiliki tugas monitoring dan pengawasan kredit/pembiayaan yang telah disalurkan. Kegiatan monitoring ini diperlukan sebagai upaya peringatan dini (earling warning) untuk mengantisipasi tandatanda penyimpangan dari syarat-syarat yang telah disepakati antara debitur/mudharib dengan bank, khususnya kegiatan monitoring yang diperlukan untuk mengantisipasi menurunnya kualitas kredit /pembiayaan. Untuk menentukan tingkat kualitas/ kolektibilitas kredit yang bersangkutan, dalam kebijakan perkreditan bank setiap petugas bank harus mengatur dan mencantumkan tata cara penyelamatan dan penyelesaian kredit/ pembiayaan bermasalah (non performing finance-NPF).

\section{Revenue Sharing}

Untuk mendapat keuntungan dari usahanya, bank syariah memakai sistem bagi-hasil. Kalau dalam bank konvensional yang menerapkan sistem bunga, penentuan suku bunga dibuat pada waktu akad dengan pedoman harus selalu menguntungkan bank. Dalam sistem bagi-hasil tidak seperti perbankan konvensional. Penentuan besarnya bagi hasil dibuat pada waktu akad dengan berpedoman pada kemungkinan untung dan rugi. Penentuan besarnya persentase suku bunga pada bank konvensional berdasarkan pada jumlah uang (modal) yang dipinjamkan. Demikian pula, juga tidak tergantung kepada kinerja usaha. Jumlah pembayaran bunga tidak mengikat meskipun jumlah keuntungan berlipat ganda saat keadaan ekonomi sedang baik. Kewajiban pembayaran bunga tetap seperti yang di perjanjikan dalam akad tanpa pertimbangan proyek yang dijalankan oleh nasabah untung atau rugi.

Penyaluran dana pada bank syariah dalam bentuk pembiayaan mudharabah kepada sektor usaha menunjukkan adanya berbagai macam usaha yang mempunyai karakteristik biaya yang berbeda dan bermacam-macam. Bank sebagai shahibul maal kedua atau pemegang amanah shahibul maal pertama menghadapi kesulitan untuk mengakui biaya-biaya usaha yang dikeluarkan oleh pengusaha atau nasabah sebagai mudharib. Padahal biaya-biaya yang sulit diversifikasi inilah yang kemudian menjadi pengurang seluruh pendapatan yang akan dibagihasilkan. Perhitungan pendapatan dengan pendekatan revenue sharingakan lebih mudah. Cara ini sangat membantu bank di mana bank tidak memerlukan petugas yang memiliki spesifikasi khusus tentang bisnis tertentu untuk dapat melakukan kontrol terhadap biaya-biaya yang dikeluarkan oleh nasabah jika dibandingkan dengan perhitungan nisbah dengan menggunakan profit sharing.Namun dalam hal ini tidak semua pembiayaan mudharabah menggunakan revenue sharing.

Menurut Muhammad (2000) ketentuan agunan dalam pembiayaan mudharabah adalah sebagai berikut: (a) Secara prinsip dalam konsep mudharabah tidak ada jaminan yang diambil sebagai agunan dan (b) Jaminan dapat diambil untuk menjaga agar nasabah benar-benar melaksanakan usaha dengan baik. Dalam incentive compatible constraints penetapan agunan berupa aset tetapakan mencegah mudharib melakukan penyelewengan karena jaminan yang sudah diberikannya itu menjadi harga dari penyelewengan atas perilakunya (character risk). 
Maksud dari ketentuan-ketentuan tersebut adalah bank dalam memberikan pembiayaan mudharabah diperkenankan mengambil jaminan, tetapi pencairannya hanya dapat dilakukan bilamana nasabah: (a) terbukti melakukan pelanggaran (penyimpangan) terhadap syarat dan kondisi akad; (b) lalai; dan/atau (c) curang. Hal ini berarti untuk pembiayaan mudharabah dan musyarakah pengenaan jaminan tidak berfungsi sebagai second way-out, pengganti pengembalian modal yang ditanamkan bank pada usaha/proyek nasabah, tetapi sebagai ganti rugi adanya pelanggaran, kelalaian dan kecurangan nasabah.

Pembagian keuntungan diantara dua pihak tentu saja harus berdasarkan proporsi dan tidak memberikan keuntungan sekaligus atau yang pasti kepada shahibul maal (bank). Bank tidak bertanggung jawab atas kerugian-kerugian di luar modal yang telah diberikannya. Bank hanya bertanggung jawab atas jumlah modal yang telah ditanamkan dalam pembiayaan. Untuk alasan inilah mudharib tidak diizinkan mengikat kontrak mudharabah dengan suatu jumlah yang melebihi modal yang telah ditanamkan oleh bank dalam kontrak tersebut. Setiap komitmen seperti itu harus dengan persetujuan bank. Namun jika mudharib melakukan kesalahan dan mengabaikan kesepakatan bersama dengan bank, maka situasi demikian akan menjadi tanggung jawab mudharib atas segala kerugian dan biaya yang di akibatkan oleh pelanggaran itu.

Terdapat kelemahan dengan menggunakan revenue sharing yaitu terjadinya shrinking risk bahwa bila nasabah tidak mampu menanggung biaya (nafaqah) yang seharusnya ditanggung nasabah, sehingga nasabah tidak mampu melanjutkan usahanya. Shringking risk tersebut disebabkan adanya unusual bussiness risk yaitu resiko bisnis yang luar biasa yang ditentukan oleh: (a) penurunan drastis tingkat penjualan bisnis yang dibiayai dan (b) penurunan drastis harga jual barang/jasa dari bisnis yang dibiayai.

Setelah menganalisis pertimbangan-pertimbangan kelima alternatif tersebut di atas yakni: maksimal hutang terhadap modal nasabah, maksimal aset tetap terhadap total aset, monitoring atau pengawasan, penetapan revenue sharing, dan perhitungan dan pembayaran zakat, maka selanjutnya adalah pengambilan keputusan. Dengan mengacu pada nilai-nilai perusahaan sebagai indikator dalam memilih alternatif pemecahan masalah maka peneliti dapat menarik kesimpulan bahwa alternatif ketiga merupakan alternatif terbaik. Keputusan untuk melakukan kontrol atau monitoring merupakan upaya pengamanan yang diberikan oleh bank dengan jalan terus memantau dan mengikuti jalannya perusahan nasabah baik secara langsung maupun tidak langsung guna menghindari terjadinya penyimpangan-penyimpangan dengan cara mendorong dipatuhinnya konvenan (syarat) pembiayaan yang telah ditetapkan serta memberikan saran dan konsultasi agar perusahaan nasabah berjalan dengan baik.

\section{SIMPULAN DAN SARAN}

Berdasarkan pada hasil pengumpulan data, pengelolaan data, serta analisis data dengan landasan teori sebagaimana telah diuraikan pada bab-bab sebelumnya, dapat diambil beberapa kesimpulan sebagai berikut:

1. Hasil analisis risiko pembiayaan mudharabah pada Bank BTN Kantor Cabang Syariah Malang tahun 2006-2009 dapat disimpulkan hal-hal sebagai berikut:

a. Risiko Pembiayaan Mudharabah

Risiko pembiayaan mudharabah antara lain: pertama, asimetri informasi problem yaitu kecenderungan salah satu pihak yang menguasai informasi lebih banyak untuk bersikap tidak jujur, kedua, side streaming yaitu nasabah menggunakan dana itu bukan seperti yang disebut dalam kontrak dan ketiga, lalai dan kesalahan yang disengaja.Pada akad pembiayaan mudharabah, bank sebagai shahib almaal mempercayakan sejumlah modal kepada pengelola mudharib dengan suatu perjanjian yang disepakati.Pihak mudharib diberikan hak aktif atas usaha, dan sebaliknya pihak bank tidak.

b. Pengawasan pada pembiayaan Mudharabah Untuk menghadapi kemungkinan risiko bank syariah diperkenankan untuk melakukan pengawasan baik secara aktif dengan melakukan pemeriksaan secara langsung terhadap operasional maupun berkas-berkas nasabah maupun secara pasif dengan menerima laporan dari nasabah. Bank sebagi pemilik modal melakukan pengawasan (monitoring) dan mudharib melakukan pembatasan atas tindakan-tindakannya (bonding).

c. Meminimalisasi Risiko Pembiayaan Mudharabah

Untuk meminimalisasi risiko pada pembiayaan akad mudharabah, bank dapat menetapkan syarat-syarat atau konvenan tertentu dengan cara menetapkan struktur insentif kepada pelaku usaha. 


\section{Saran}

1. Permasalahan penyimpangan atau asymmetric information dalam kontrak mudharabah dapat diminimalisasi dengan cara menetapkan struktur insentif kepada pelaku usaha. Batasan atau konvenan (syarat) berikut merupakan dari proses meminimalisasi risiko yaitu dengan melakukan monitoring dan supervisi bank.

2. Hal-hal yang perlu dilakukan adalah membuka konsep-konsep pembiayaan yang masih mungkin digulirkan, dengan prosedur yang lebih mudah dan tetap hati-hati. Beberapa perbaikan berkaitan dengan problema tersebut adalah peningkatan mutu sistem pembiayaan yang lebih baik. Secara riil adalah meminimalisasi transaksi jual-beli dan memprioritaskan pembiayaan kepada sektor riil yang membuka peluang lapangan pekerjaan.

3. Pengimplementasian pembiayaan akad mudharabah memerlukan kecermatan tenaga, waktu, biaya pada sistem monitoring yang berkelanjutan, dan yang paling utama adalah membangun dukungan dan komitmen yang kuat dari para staf/karyawan serta pimpinan bank untuk mensosialisasikan serta mengkoordinasikan dengan baik dalam lingkungan perbankan syariah.

\section{DAFTAR REFERENSI}

Antonio, M. S. 2003. Bank Syariah; dari Teori ke Praktek, Jakarta: Gema Insani Press.
Firdaus, H. R. \& Aryanti, M. 2003. Manajemen Perkreditan Bank Umum. Bandung: Alfabeta.

Harisman. 2002. Tugas Bank Indonesia dalam Pengawasan dan Pembinaan Perbankan Syari'ah di Indonesia, Jurnal Hukum Bisnis, Volume 20, Agustus-September 2002, Jakarta: Yayasan Pengembangan Hukum Bisnis (YPHB).

Karim, A., 2001. Perbankan Syari'ah: Peluang, Tantangan dan Strategi Pengembangan, Jurnal Agama, Filsafat dan Sosial, 3(3): 33.

------. 2005. Analisis Fiqih danKeuangan, Jakarta: IIIT Indonesia.

Muhammad. 2000. Prinsip-Prinsip Akuntansi dalam Al Qur'an, Yogyakarta: UII Press. -. 2002. Pengantar Akuntansi Syariah, Jakarta: Salemba Empat.

---. 2005. Bank Sharia Problem danProspek Perkembangan Di Indonesia, Cetakan Pertama. Yogyakarta: Graha Ilmu.

Sudarsono, H. 2004. Bank dan Lembaga Keuangan Syari'ah, Deskripsi dan Ilustrasi. Edisi Kedua. Yogyaakrta: Ekonisia FEUII.

Triyuwono, I. 1997. Akuntansi Syari'ah dan Koperasi: Mencari Bentuk Dalam Bingkai Metafora Amanah, Jurnal Akuntansi dan Auditing Indonesia. 1(1): 3-45.

Triyuwono, I. \& As'udi, M. 2001. Akuntansi Syariah: Memformulasikan Konsep Laba dalam Konteks Metafora Zakat, Jakarta: Salemba Empat. 